\title{
Knowledge and attitudes towards dementia among final-year medical students in Brazil
}

\author{
Alessandro Ferrari Jacinto ${ }^{1 *}$, Vanessa de Albuquerque Citero², José Luiz de Lima Neto ${ }^{3}$, Paulo José Fortes Villas Boas ${ }^{4}$, \\ Adriana Polachini do Valle ${ }^{4}$, Ananda Ghelfi Raza Leite 5 \\ ${ }^{1}$ PhD, Assistant Professor, Department of Internal Medicine, Faculdade de Medicina de Botucatu da Universidade Estadual Paulista “Júlio de Mesquita Filho” (FMB-Unesp), Botucatu, SP, Brazil \\ ${ }^{2}$ Associated Professor, Department of Psychiatry, Escola Paulista de Medicina da Universidade Federal de São Paulo (EPM-Unifesp), São Paulo, SP, Brazil \\ ${ }^{3}$ Medical Student, FMB-Unesp, Botucatu, SP, Brazil \\ ${ }^{4} \mathrm{PhD}$, Assistant Professor, Department of Internal Medicine, FMB-Unesp, Botucatu, SP, Brazil \\ ${ }^{5}$ Psychologist, MSc Student, Collective Health Graduate Program, FMB-Unesp, Botucatu, SP, Brazil
}

Study conducted at Faculdade de Medicina de Botucatu da Universidade Estadual Paulista (FMB-Unesp), Botucatu, and Escola Paulista de Medicina da Universidade Federal de São Paulo (EPM-Unifesp), São Paulo, SP, Brazil

Article received: 9/17/2016 Accepted for publication: 10/19/2016

*Correspondence: Address: Distrito de Rubião Jr, s/n Botucatu, SP - Brazil Postal code: 18618-970 alessandrojacinto@uol.com.br

http://dx.doi.org/10.1590/1806-9282.63.04.366

\section{SUMmARY}

Objective: Among all countries, Brazil is expected to have the sixth largest elderly population in 2025. Dementia syndromes are prominent among aging-related diseases. Despite the necessity of and curriculum for training in geriatric medicine to make recommendations on an approach to this theme, adequate training appears to be infrequent. The present study aimed to evaluate the knowledge about dementia and students' attitude towards it during the last semester of the medical course in two of the most important Brazilian medical schools.

Method: In our study, a sample of 189 students was invited to complete questionnaires comprising demographic and professional topics, knowledge with respect to cognitive alterations in the elderly and attitudes in dealing with an elderly patient with dementia.

Results: A total of 155 students accepted to participate in the study; 92(59.7\%) considered that they had good training in cognitive alterations during their undergraduate medical course, while 67 (58.8\%) of them declared having had only theoretical training. Regarding knowledge, the students obtained a mean of 6.9, out of a scale from 0 to 14 points. As for attitudes, the students agreed that they can contribute to the life quality of the patient and of the caregiver, and that it is useful to provide the diagnosis to the family.

Conclusion: The findings of this study are relevant for overturn the educational barriers of physicians in relation to the care of patients with dementia.

Keywords: aged, dementia, health knowledge, attitudes and practice in health, medical students.

\section{INTRODUCTION}

Aging of the population is a worldwide phenomenon. ${ }^{1}$ Among countries in 2025, Brazil is expected to have the sixth highest number of the elderly. ${ }^{2}$ Dementia syndromes are prominent among aging-related diseases, and dementia from Alzheimer's disease (AD) is the most prevalent. In the USA, in 2015, about 5.3 million persons were diagnosed with $\mathrm{AD} .{ }^{3}$ In Brazil, projections indicate that the prevalence of dementia will rise, reaching $7.9 \%$ of the elderly aged 65 years or older by $2020 .^{2}$

Early diagnosis of dementia allows the patient to have access to several treatment options, as well as appropriate multidisciplinary care, facilitating the planning of future care. ${ }^{3}$ However, studies show that patients with dementia are not diagnosed, especially by a general practitioner. ${ }^{4-6}$ In Brazil, a single published study showed that cognitive decline of the elderly is infrequently detected by general practitioners. ${ }^{4}$ Many physicians who have recently graduated from medical school opt for working in the Brazilian Public Health System, which is responsible for attending to about $75 \%$ of the population. ${ }^{7}$ Despite the necessity of and curriculum for training in geriatric medicine to make recommendations on an approach to this theme, adequate training appears to occur infrequently. ${ }^{8}$ 
In Brazil, the National Policy for the Elderly has among its main guidelines the promotion of healthy aging including assistance to obtain specific necessities for the health of the elderly together with training of specialized human resources. Despite this law, there is a notorious lack of professionals with specialized training for attending the demands of this population. ${ }^{9}$

The Brazilian government has invested in the reorganization of basic medical attention, trying to make academic products (professionals, knowledge and services) adequate for social needs. ${ }^{10}$

In this context, the present study aimed to evaluate the knowledge about dementia and students' attitude towards it during the last semester of the medical course in two of the most important Brazilian medical schools.

\section{Method}

The project was approved by the Committee for Research Ethics of the two institutions involved.

A sample of 189 students included 74 students from Faculdade de Medicina de Botucatu, São Paulo State University (FMB-Unesp), and 115 from Escola Paulista de Medicina, Federal University of São Paulo (EPM-Unifesp). Five students from FMB-Unesp were lost (who did not sign the Free and Informed Consent Term), as well as 29 students from EPM-Unifesp (ten with whom contact could not be made and 19 who alleged lack of time for data collection). The final sample included 155 (89\%) students, 69 from FMB-Unesp (93\% of FMB population) and 86 from EPM-Unifesp (75\% of EPM population).

The inclusion criterion was to be properly enrolled in the undergraduate medical course of one of the two medical schools; there were no criteria for exclusion.

The participants were invited to answer three questionnaires: 1) Demographic and professional questionnaire developed by the researchers for this specific study, which describes the profile of medical training and their prior training to detect cognitive alterations; 2) Questionnaire of the knowledge of the physician with respect to cognitive alterations in the elderly; and 3) Questionnaire on attitudes in dealing with an elderly patient with dementia. ${ }^{8,11}$ Questionnaires 2 and 3 were culturally adapted to Brazil and published elsewhere. ${ }^{11}$

The responses to questionnaire 1 were displayed as absolute and relative numbers. The frequencies of correct responses regarding general knowledge (questions 1 to 14), epidemiological knowledge (questions 1 to 5), diagnostic knowledge (questions 6 to 11) and management knowledge (questions 12 to 14) were obtained from questionnaire 2. Questionnaire 3 provided frequencies of responses for each question.

\section{Results}

The total of students evaluated was 155 . Their mean age was 25.20 at FMB-Unesp (SD $=1.8)$ and 25 years at EPM-Unifesp (SD = 1.8).

According to Table 1, 92 (59.74\%) considered that they had good training in cognitive alterations during their undergraduate medical course, while $67(58.8 \%)$ of them declared having had only theoretical training. As to extracurricular courses, 142 (93.42\%) reported taking them during their undergraduate course.

According to Table 2, questions 3, 4, 5, 7, 8, 11 and 12 yielded a higher percentage of correct answers. The students obtained a mean of 6.9 points in the general knowledge section of the questionnaire, based on a total scoring scale from 0 to 14 points.

According to Table 3, the students agreed that they can contribute to the quality of life of both patient and caregiver, and that it is useful to provide the diagnosis to the family.

\section{Discussion}

The present study is pioneering in the verification of the knowledge about dementia and Brazilian medical students' attitude towards it. We observed that most students recalled having had good fundamental knowledge in cognitive alterations during their undergraduate medical course, which would have been essentially theoretical, while almost all reported taking extracurricular courses on the subject during their undergraduate course.

We did not find any research studies in the literature that dealt with the study of knowledge and attitudes of students in the final year of medical school regarding patients with dementia. A single Brazilian study has investigated knowledge and attitudes towards dementia by medical residents. ${ }^{12}$

The results of our study regarding the profile of training received by the students during the medical course contrast with other studies in the area, given that 92 $(59.74 \%)$ of the students analyzed reported having received good training in cognitive alterations, whereas in the other studies, there was variation from 29 to $47.6 \%{ }^{8,13,14}$

The medical students analyzed achieved a mean of 6.9 in the general score of the knowledge questionnaire (on a scale ranging from 0 to 14 points), with the highest percentage of correct answers being in questions on epidemiology. A study ${ }^{15}$ from 2010 that compared general practitioners who graduated in 1990 and those recently trained revealed that, in general, the score of correct answers was low (between zero and two out of 10 questions), observing that the gap in graduation time did not determine significant differences in relation to knowledge in dementia. Similarly, an- 
TABLE 1 Aspects of the medical students' training in dementia during their undergraduate program.

\begin{tabular}{|c|c|c|c|}
\hline Item & Students from FMB-Unesp & Students from EPM-Unifesp & Total \\
\hline \multicolumn{4}{|l|}{ Sex } \\
\hline Male & $27(17.42 \%)$ & $51(32.90 \%)$ & $78(50.32 \%)$ \\
\hline Female & $42(27.10 \%)$ & $35(22.58 \%)$ & $77(49.68 \%)$ \\
\hline \multicolumn{4}{|c|}{ Did you have good training in cognitive alterations? } \\
\hline Yes & $41(26.62 \%)$ & $51(33.12 \%)$ & $92(59.74 \%)$ \\
\hline No + do not remember & $27(17.53 \%)$ & $35(22.73 \%)$ & $62(40.26 \%)$ \\
\hline Did not respond & & 1 & \\
\hline \multicolumn{4}{|c|}{ If yes, the training in cognitive alterations was: } \\
\hline Only theoretical & $27(23.68 \%)$ & $40(35.09 \%)$ & $67(58.77 \%)$ \\
\hline Theoretical and practical & $25(21.93 \%)$ & $22(19.30 \%)$ & $47(41.23 \%)$ \\
\hline Did not respond & 17 & 24 & \\
\hline \multicolumn{4}{|c|}{ Have you taken any extracurricular courses on the subject? } \\
\hline Yes & $62(40.79 \%)$ & $80(52.63 \%)$ & $142(93.42 \%)$ \\
\hline No & $5(3.29 \%)$ & $5(3.9 \%)$ & $10(6.58 \%)$ \\
\hline Did not respond & 2 & & \\
\hline
\end{tabular}

\section{TABLE 2 Correct answers in the knowledge questionnaire.}

\section{Question}

1. General clinic with a list of 1,000 persons aged 60 years or older must wait to have the following approximate number of persons with dementia on this list:

. Starting from 65 years of age, the prevalence of dementia is: $\quad 43(27.74 \%)$

3. One of the risk factors for developing Alzheimer's disease is:

$125(80.65 \%)$

4. All of the following are potentially treatable etiologies of dementia, except:

$119(76.77 \%)$

5. Patients with suspected dementia must be evaluated as soon as possible, since:

$96(61.94 \%)$

6. Which of the following procedures is necessary to confirm definitively that the symptoms

$20(12.90 \%)$ are caused by dementia?

$\frac{n}{n}$

7. Which of the alternatives is not necessary in the initial evaluation of a patient with

$126(81.29 \%)$ suspected dementia?

8. Which of these alternatives can resemble dementia?

$125(81.29 \%)$

9. When a patient presents a sudden onset of confusion, disorientation and incapacity to

$33(21.29 \%)$ maintain attention, this clinical picture is more compatible with a diagnosis of:

10. Which of the following options is almost always present in dementia? $\quad 9(5.81 \%)$

11. Which of the following clinical findings best differentiate vascular dementia from the $106(68.39 \%)$ dementia of Alzheimer's disease?

\pm 12. The effect of anti-dementia medications act on:

13. Which statement on the treatment of demented patients with depression is true?

$60(38.71 \%)$

14. For what purpose does the ABRAZ Brazilian association supply information to patients and caretakers? 


\begin{tabular}{|c|c|c|c|c|c|}
\hline Attitudes & $\begin{array}{l}\text { Agree } \\
\text { completely (1) }\end{array}$ & Agree (2) & $\begin{array}{l}\text { Neither agree } \\
\text { nor disagree ( } 3 \text { ) }\end{array}$ & Disagree (4) & $\begin{array}{l}\text { Disagree } \\
\text { completely (5) }\end{array}$ \\
\hline $\begin{array}{l}\text { 1. Much can be done to improve the quality of } \\
\text { life of caregivers of persons with dementia }\end{array}$ & $\begin{array}{l}106 \\
(69.74 \%)\end{array}$ & $\begin{array}{l}42 \\
(27.63 \%)\end{array}$ & $\begin{array}{l}4 \\
(2.63 \%)\end{array}$ & - & - \\
\hline $\begin{array}{l}\text { 2. The families prefer to be informed about the } \\
\text { dementia of their relative as rapidly as possible }\end{array}$ & $\begin{array}{l}55 \\
(36.18 \%)\end{array}$ & $\begin{array}{l}61 \\
(40.13 \%)\end{array}$ & $\begin{array}{l}29 \\
(19.08 \%)\end{array}$ & $\begin{array}{l}6 \\
(3.95 \%)\end{array}$ & $\begin{array}{l}1 \\
(0.66 \%)\end{array}$ \\
\hline $\begin{array}{l}\text { 3. Much can be done to improve the quality of } \\
\text { life of persons with dementia }\end{array}$ & $\begin{array}{l}97 \\
(63.82 \%)\end{array}$ & $\begin{array}{l}53 \\
(34.87 \%)\end{array}$ & $\begin{array}{l}2 \\
(1.32 \%)\end{array}$ & - & - \\
\hline $\begin{array}{l}\text { 4. Providing the diagnosis is generally more } \\
\text { useful than harmful }\end{array}$ & $\begin{array}{l}71 \\
(46.71 \%)\end{array}$ & $\begin{array}{l}69 \\
(45.39 \%)\end{array}$ & $\begin{array}{l}10 \\
(6.58 \%)\end{array}$ & $\begin{array}{l}2 \\
(1.32 \%)\end{array}$ & - \\
\hline $\begin{array}{l}\text { 5. Dementia is better diagnosed in specialized } \\
\text { service units }\end{array}$ & $\begin{array}{l}45 \\
(29.61 \%)\end{array}$ & $\begin{array}{l}59 \\
(38.82 \%)\end{array}$ & $\begin{array}{l}29 \\
(19.08 \%)\end{array}$ & $\begin{array}{l}18 \\
(11.84 \%)\end{array}$ & $\begin{array}{l}1 \\
(0.66 \%)\end{array}$ \\
\hline $\begin{array}{l}\text { 6. The patients with dementia can drain resources } \\
\text { with little positive result }\end{array}$ & $\begin{array}{l}5 \\
(3.33 \%)\end{array}$ & $\begin{array}{l}39 \\
(26 \%)\end{array}$ & $\begin{array}{l}42 \\
(28 \%)\end{array}$ & $\begin{array}{l}55 \\
(36.67 \%)\end{array}$ & $\begin{array}{l}9 \\
(6 \%)\end{array}$ \\
\hline $\begin{array}{l}\text { 7. It is better to speak with the patient utilizing } \\
\text { euphemisms }\end{array}$ & - & $\begin{array}{l}3 \\
(1.97 \%)\end{array}$ & $\begin{array}{l}27 \\
(17.76 \%)\end{array}$ & $\begin{array}{l}87 \\
(57.24 \%)\end{array}$ & $\begin{array}{l}35 \\
(23.03 \%)\end{array}$ \\
\hline $\begin{array}{l}\text { 8. Treating dementia tends to be more frustrating } \\
\text { than gratifying }\end{array}$ & $\begin{array}{l}3 \\
(2.01 \%)\end{array}$ & $\begin{array}{l}18 \\
(12.08 \%)\end{array}$ & $\begin{array}{l}49 \\
(32.89 \%)\end{array}$ & $\begin{array}{l}66 \\
(44.30 \%)\end{array}$ & $\begin{array}{l}13 \\
(8.72 \%)\end{array}$ \\
\hline $\begin{array}{l}\text { 9. Directing families to specialized services is } \\
\text { not worth the effort when they do not want to } \\
\text { use them }\end{array}$ & $\begin{array}{l}1 \\
(0.66 \%)\end{array}$ & $\begin{array}{l}25 \\
(16.56 \%)\end{array}$ & $\begin{array}{l}37 \\
(24.50 \%)\end{array}$ & $\begin{array}{l}73 \\
(48.39 \%)\end{array}$ & $\begin{array}{l}15 \\
(9.93 \%)\end{array}$ \\
\hline $\begin{array}{l}\text { 10. The primary care team has a very limited role in } \\
\text { the care of persons with dementia }\end{array}$ & $\begin{array}{l}3 \\
(1.97 \%)\end{array}$ & $\begin{array}{l}12 \\
(7.89 \%)\end{array}$ & $\begin{array}{l}15 \\
(9.87 \%)\end{array}$ & $\begin{array}{l}77 \\
(50.66 \%)\end{array}$ & $\begin{array}{l}45 \\
(29.61 \%)\end{array}$ \\
\hline
\end{tabular}

other study ${ }^{8}$ found that general practitioners presented a low level of knowledge in dementia and in that same study they obtained worse scores in questions of epidemiology and found that poorer general knowledge in dementia was associated with less communication of the dementia diagnosis to the patients. Based on this, the authors concluded that educational support should be concentrated on epidemiological knowledge. Thus, the possibility may be considered that, in prior studies, if the students herein evaluated, upon commencing as professionals, would maintain open communication with their patients as was shown in "attitude four" in which 71 (46.71\%) of the students agreed that "Providing a diagnosis generally is more useful than harmful," demonstrating a positive attitude in relation to communication with demented patients.

Most of the students demonstrated a positive attitude toward $\mathrm{AD}$ patients, a fact corroborated by previous studies that found an association between diagnostic competence (related to knowledge) and positive general attitudes. ${ }^{8,16,17}$

Despite the expressive increase in this social and professional demand worldwide, little has been accomplished in relation to the training of professionals in dementia. ${ }^{18}$ A study involving 14 European countries found that little has been done in relation to the training of professionals in dementia and that, in many countries, there are no educational programs directed toward this matter nor financial support. ${ }^{19}$ Based on this premise, aging-related diseases must be part of the curriculum of medical students recommended in the curricular correspondence matrix..$^{20,21}$ Training of these professionals is of vital importance, and must focus on the attitudes of medical students, which are molded during their years of training, given that such attitudes have great impact on the care provided to elderly patients when they become health professionals. Thus, so that these professionals may diagnose and treat adequately, it becomes necessary that they have greater proximity to the care of demented seniors. ${ }^{22}$

Some limitations must be considered: only two medical schools were analyzed among 268 throughout Brazil; ${ }^{23}$ the curricula were not analyzed in detail; the specific instrument utilized in our research cannot cover the questions and attitudes considered in the most exhaustive and adequate manner possible. In this manner, the comparisons made must be analyzed with caution as they deal with different populations (students in their final year of medical school versus graduated physicians), keeping in 
mind that the literature on these topics is scarce for final-year medical students' considering the knowledge and attitudes related to patients with dementia.

In conclusion, the findings of our study are relevant for introducing and implementing the knowledge and attitudes that would help overcome the educational obstacles of physicians in relation to the care of patients with $\mathrm{AD}$.

\section{ACKNOWLEDGMENTS}

We thank the medical students for accepting to participate in the study.

\section{Conflict of Interest}

The authors declare no conflict of interest.

\section{Resumo}

Conhecimentos e atitudes em relação à demência de estudantes de medicina brasileiros no final da graduação

Objetivo: Em 2025, o Brasil terá a sexta maior população de idosos do mundo. Destacam-se, dentre as doenças relacionadas com o envelhecimento, as síndromes demenciais. Apesar da necessidade de o currículo para a formação médica conter tópicos em geriatria, isso parece ocorrer com pouca frequência. O presente estudo tem como objetivo avaliar conhecimento e atitudes em relação à demência de alunos do último semestre do curso médico em duas das mais importantes escolas médicas brasileiras. Método: Neste estudo, 189 alunos foram convidados a responder questionários que compreendem temas demográficos e profissionais, conhecimento sobre alterações cognitivas em idosos e atitudes frente a um paciente idoso com demência.

Resultados: Um total de 155 estudantes aceitou participar do estudo; $92(59,7 \%)$ relataram ter obtido uma boa formação em alterações cognitivas durante o curso de graduação em medicina, e, entre estes, 67 (58,8\%) relataram ter tido apenas uma base teórica. Quanto ao conhecimento, os alunos obtiveram uma média de 6,9, considerando uma escala de pontuação de 0 a 14 pontos. Considerando as atitudes, os estudantes concordaram que eles podem contribuir para a qualidade de vida do paciente e de cuidadores, e que é útil dar o diagnóstico para a família.

Conclusão: Os resultados deste estudo são relevantes para discutir as barreiras educacionais dos médicos em relação ao tratamento de pacientes com demência.
Palavras-chave: idoso, demência, conhecimentos em saúde, atitudes e práticas em saúde, estudantes de medicina.

\section{References}

1. Souza L, Galante H, Figueiredo D. Quality of life and the elderly well-being: an exploratory study in the Portuguese population. Cad Saúde Pública. 2003; 37(3):364-71

2. World Health Organization. Active aging: a health policy. Brasília: Pan American Health Organization; 2005.

3. Alzheimer's Association. 2015 Alzheimer's disease facts and figures. Alzheimers Dement. 2015; 11(3)332-84.

4. Jacinto AF, Brucki SMD, Porto CS, Martins, MA, Nitrini R. Detection of cognitive impairment in the elderly by general internists in Brazil. Clinics (Sao Paulo). 2011; 66(8):1379-84.

5. Valcour VG, Masaki H, Curb JD, Blanchette PL. The detection of dementia in the primary care setting. Arch Intern Med. 2000; 160(19):2964-8.

6. Finkel SI. Cognitive screening in the primary care setting: the role of physicians at the first point entry. Geriatrics. 2003; 58(6):43-4.

7. Neurological Disorders: public health challenges. Geneve: World Health Organization; 2006.

8. Turner S, Iliffe S, Downs M, Wilcock J, Bryans M, Levin E, et al. General practitioners' knowledge, confidence and attitudes in the diagnosis and management of dementia. Age Ageing. 2004; 33(5):461-7.

9. Brasil. Lei $\mathrm{N}^{\circ} 8.842,4$ de janeiro 1994. Dispõe sobre a política nacional do idoso. [cited 2016 Jul 6]. Available from: http://www.planalto.gov.br/ccivil_03/leis/L8842.htm.

10. Ministério da Saúde. Ministério da Educação. Secretaria de Políticas de Saúde. Secretaria do Ensino Superior. Projeto de incentivo a mudanças curriculares em cursos de medicina. Brasília; 2001. [cited 2015 Jun 23]. Available from: http://portal.mec.gov.br/sesu/arquivos/pdf/inc.pdf.

11. Jacinto AF, Oliveira EC, Citero VA. Brazilian transcultural adaptation of an instrument on physicians' knowledge and attitudes towards dementia Dement Neuropsychol. 2015; 9(3):245-50.

12. Jacinto AF, Boas PJFV, Mayoral VFS, Citero VA. Knowledge and attitudes towards dementia in a sample of medical residents from a university-hospital in São Paulo, Brazil. Dement Neuropsychol. 2016; 10(1):37-41.

13. Renshaw J, Scurfield LC, Orrel M. General practitioner's views on the early diagnosis of dementia. Br J Gen Pract. 2001; 51(462):37-8.

14. Wolff LE, Woods JP, Reid J. Do general practitioners differ in their attitudes to dementia? Int J Geriatr Psychiatry. 1995; 10(1):63-9.

15. Ahmad S, Orrel M, Illife S, Gracie A. GPs' attitudes, awareness, and practice regarding early diagnosis of dementia. Br J Gen Pract. 2010; 60(578):e360-5.

16. Kaduszkiewicz H, Wiese B, van den Bussche H. Self-reported competence, attitude and approach of physicians towards patients with dementia in ambulatory care: results of postal survey. BMC Health Serv Res. 2008; 8:54

17. Olafsdóttir M, Foldevi M, Marcusson J. Dementia in primary care: why the low detection rate? Scand J Prim Health Care. 2001; 19(3):194-8.

18. Tsolaki M, Papaliagkas V, Anogianakis G, Bernabei R, Emre M, Frolich L, et al.; European Alzheimer Disease Consortium. Consensus statement on dementia education and training in Europe. J Nutr Health Aging. 2010; 14(2):131-5.

19. Hasselbalch SG, Baloyannis S, Denislic M, Dubois B, Oertel W, Rossor M, et al. Education and training of European neurologists in dementia. Eur J Neurol. 2007; 14(5):505-9.

20. Tullo ES, Gordon AL. Teaching and learning about dementia in UK medical schools: a national survey. BMC Geriatr. 2013; 13:13:29.

21. Brazil. Ministry of Education. Department of Higher Education. Ministry of Health Secretariat of Labor Management and Health Education. Curriculum correlation matrix for revalidation purposes of medical degrees obtained abroad / Ministry of Education, Ministry of Health. Brasília: MEC, MS; 2009.

22. George DR, Stuckey HL, Whitehead MM. An arts-based intervention at a nursing home to improve medical students' attitudes toward persons with dementia. Acad Med. 2013; 88(6):837-42.

23. Nassif CAN. [Revalidation of medical school certificates in Brazil]. [cited 2016 Apr 10]. Available from: http://www.escolasmedicas.com.br/. 